\section{電子計算機による体格・体力朗定资料の藮計と順位 其出による体育英技クラスの決定について}

㓅治学完大学

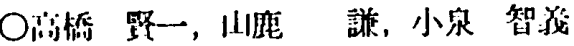

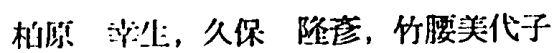

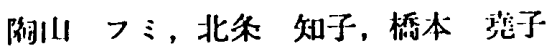

\section{目的}

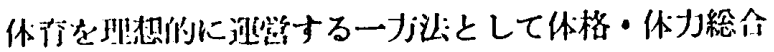

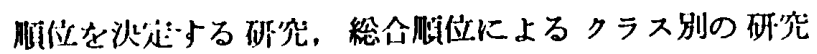

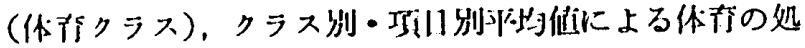

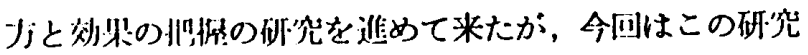

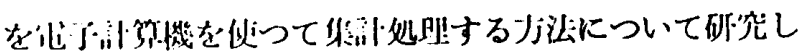

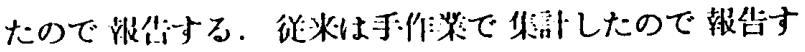

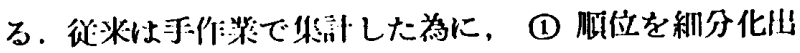

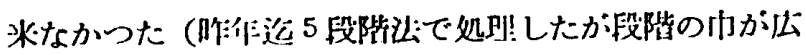

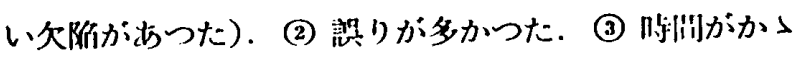

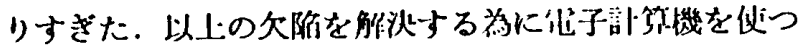
た。

\section{順位及び体育クラス決定の方法}

似川㙨械以パンチカードのカラム数（闌数）の多いレ

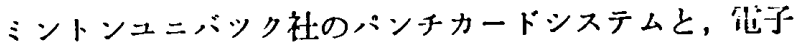

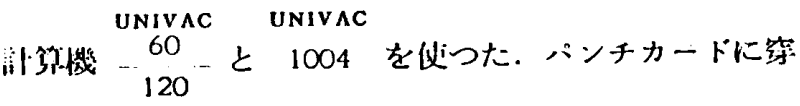

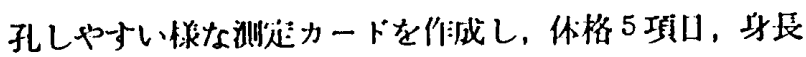

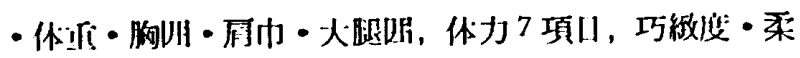

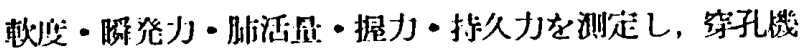
によつて】カートにハンチし，別図の则く，梌孔機分頪

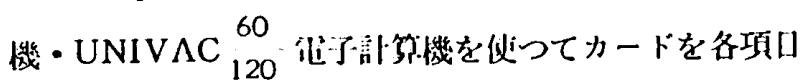

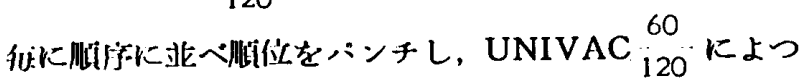

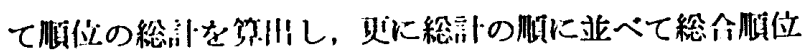

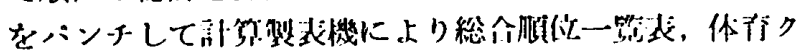

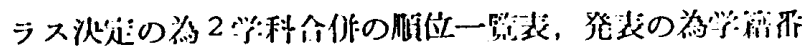

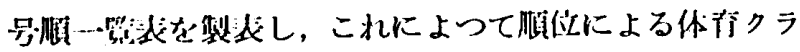

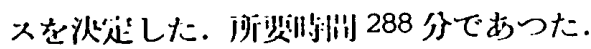

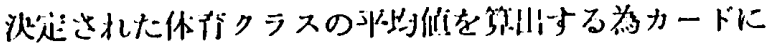

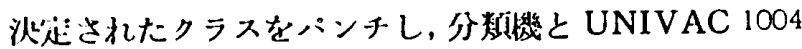

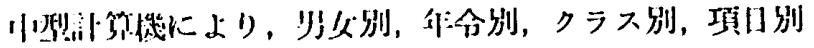

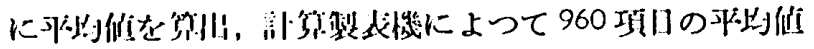

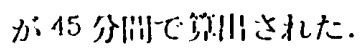

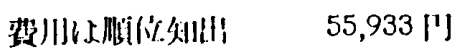

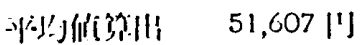

$$
\text { it 107,540们であつた。 }
$$

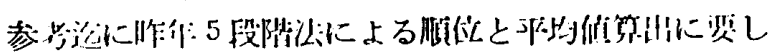

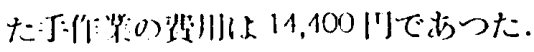

考 祭

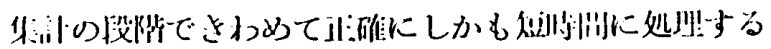

执が出来た。この方法で選別された上位クラスに実施し た $8 \mathrm{~km}$ 邀泳では，完泳深 68.9\% (29 名中20名)で全 く休格休力の俱れたクラスであつた．休格・体力の劣る

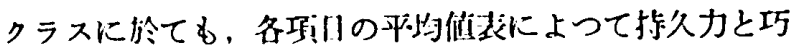

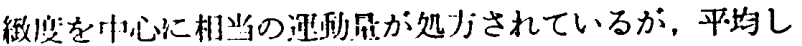

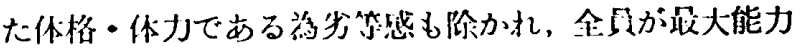
を発抓しよい意味での協力と競争が行われ，心理的にも

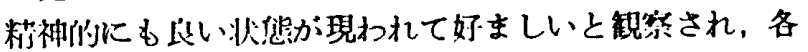
クラス其化秋の测定での効果が期待されている。

\section{むすひ}

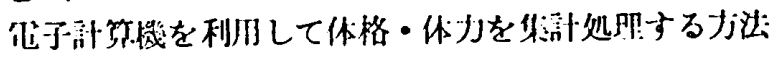
は、一度プログラムが山来てしまうと非常に简谁にしか

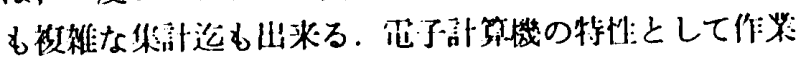
具が多い㮛コストが安くなるので、〔註. 1000 名でも10 万名でもそそ机以上でもあまり変らない，企间们小小，

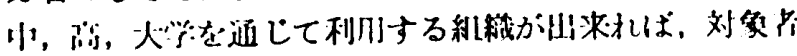

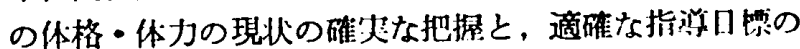

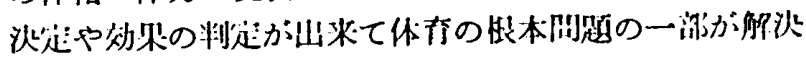
されると考える。

\section{第 1 表}

電子計算機順路表（顺位・平地草出）
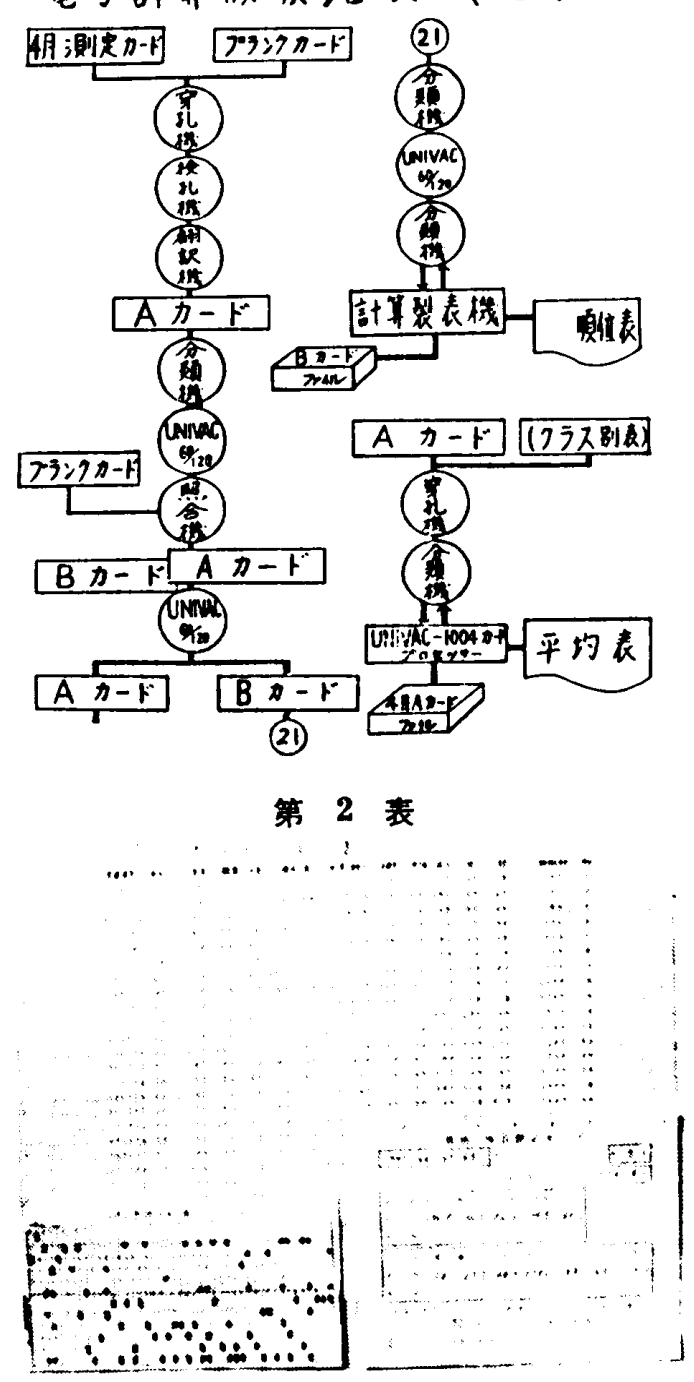